\title{
"INSIDE THE FENCE";
}

\section{THE SOCIAL BASIS OF PRIVACY IN NABENCHAUK ${ }^{1}$}

\author{
Leslie K. Havitand \\ John B. Haviland \\ Autralian National University
}

1. The guarded privacy of peasant life has long been a commonplace of European folk wisdom, and is well-established in social theory as a principle element in the notion of tradition. The privacy -and inaccessability - of the peasant has been the object of strategic manoeuvre by colonial policymakers, revolutionary cadres and agents of political and economic development. Current sociological and anthropological accounts of Mediterranean, Latin American, Asian and African peasantries revolve around the same axis. Through all these theories of society, both pragmatic and academic, run two competing images of peasants, coloured by the positive and negative aspects of privacy.

One portrait of the peasant shows him to be narrow-minded, distrustful, mean and quarrelsome, having only slightly more use for his neighbor than he has for a stranger, a thorough unbeliever in the concept of the public good, an "amoral familist" whose social ethics stop at his own front door. Peasant privacy in this picture is but another face of selfish ignorance. Competing with this unappealing fellow is the sturdy, self-reliant, openhearted salt of the earth, the unhurried husbander of nature's forces, whose elemental skills protect him from the vagaries of modern civilization. Peasant

1 A version of this paper was originally presented as a contribution to a symposium on the Public/Private Dichotomy, in the Research School of Social Sciences, Australian National University, in September 1979. We are indebted to S. I. Benn for his invitation to consider the issues involved, and to Rodney Needham for his critical comments. 
privacy in this view is the natural outcome of thoroughgoing independence.

However we choose between these two images, as soon as we begin to regard being peasant as somehow a feature of culture, we set foot upon a path which will bring us to the absurdity of saying, in essence, that peasants are people who act in this particular way, and who, therefore, tend to fill this particular social niche. Looking at peasants as bearers of a particular culture style tempts us to think of them as people left behind by the continuing development of the society around them. Peasants then are those rural people who somehow failed to change at the same rate as everyone else, people who remain rural in an urban age, remain farmers in an industrial era, remain devoted to witchcraft in the midst of a scientific revolution - in other words, peasants are inert social elements in a universe of movement, and their inertia, therefore, is a property of themselves and not of the structure of the universe. Thus, development agencies set about looking for ways to motivate peasants to change and wondering how to overcome their cultural predisposition to stagnate.

In our work in a Mexican Indian village, we too have been struck by the extreme privacy of social life. Zinacantecos have a well-developed respect for self-reliance and the security it brings, a deep distrust of relations with outsiders. One can, in the village of Nabenchauk, and, indeed, in many small farming communities around the world, track a constellation of behaviors that monitor interaction between people, that limit cooperation, and that otherwise isolate social units, of varying dimensions, from one another. We have sought in our research first to characterize this constellation of behaviors in Zinacantan. (And note that our characterization - that Zinacantecos are extremely private people - is open to dispute: we ourselves, often feel life in Zinacantan to be peculiarly exposed and constrained, as if one's every move were subject to scrutiny, were taking place in public.) Second, we have tried to discover, in the social structure of the village, in its economic and political history, and in the beliefs and understandings of its inhabitants, the sources and concomitants of this constellation of behaviors. To characterize and understand Zinacanteco social life does one begin with an ideology of privacy - with a 'peasant world view' - and trace the shoots of this root idea out into the social relations among people? Or does one begin with the complex relations between the social institutions of peasant life, and the material conditions which people 
interpret in terms of an ideology of privacy and atomism? Finally, from this work, we have aimed to portray peasant social life more generally, and to understand its determinants. In this paper we explore privacy in one Mexican Indian village - the spatial and social boundedness of households, the delineation of property and resources, the careful control of information, the cautious nature of social interaction. From detailed examples we demonstrate the relations that obtain between the social units in the villagers universe - relations that form a structure that reproduces not only the institutions of family and production through which individuals live their lives, but also the ideology of privacy itself.

2. Nabenchauk is one of a cluster of Indian villages known collectively as the township of Zinacantan, nestled in the high valleys of the mountains of Chiapas, in southern Mexico. The villages of Zinacantan share an ethnic identity signalled by their style of dress and by their dialect of Tzotzil, one of four Mayan languages in the region. Zinacanteco ethnic identity is also codified and institutionalized by a long governing tradition of colonial and republican Mexico which organized the Indian communities into civic entities with a formal political structure for purposes of intercourse with the wider legal and political framework.

Zinacantecos are the descendants of pre-Columbian people who lived on the margins of the Mayan civilization, and later as remote tributaries on Aztec trading routes. Certainly then as now they were growers of maize, beans and squash, producers of almost all their material needs, trading in a small way for specialized commodities, and providing a surplus for the metropolitan centres. We do not know, but can suppose, that the social organization of access to land followed the same lines of communal patrilineality that lowland Mayan society developed to regulate production, and the collection of tax and tribute.

The Spanish conquest reached Zinacantan within five years of the fall of the Aztec empire, and by the seventeenth century, Zinacantecos were paying tribute and organizing forced labor gangs for their new Spanish overlords. In the later years of the Colony, and throughout the pre-revolutionary Republican era, Zinacantecos progressively lost control of most of their lands. Some became debtor peons on hacienda estates; others exchanged their day labor for rights to farm the marginal lands of the ranches carved from formerly Zinacanteco lands. The return of freed peons to their ancestral villages in the twentieth century, and the tide of demographic 
increase, completely outstripped the gains made through the redistribution of land to Indian communities. Modern Zinacanteco farmers must rent land, if they are to feed themselves from their own produce, let alone to produce a surplus to exchange for cash in the marketplace. In the words of Eric Wolf:

In primitive society, surpluses are exchanged between groups or members of groups; peasants, however, are rural cultivators whose surpluses are transferred to a dominant group of rulers that uses the surpluses both to underwrite its own standard of living and to distribuite the remainder to groups in society that do not farm but must be fed for their specific goods and services in turn (Wolf, 1966: 3).

The social result of the skimming of surplus production by members of the urban based society is double. Through it the peasant is socially linked by ties of dependency, whether jural or economic, to the urban society, ties which may proliferate in a market economy. And, by this outflow of surplus production, the peasant is reduced to a subsistence economy at home. A rural subsistence economy typically produces a pattern in which all hands available in a household are turned to a broad range of productive activities of self-sustenance, each of greater or lesser profitability.

In numerous ways the social relations among villagers today, and the customary exchanges which surround and express them, show the ongoing effects of the transformation of Zinacanteco Indians into market-oriented peasants. Social obligations and expectations once satisfiable only through specific goods and services have become market relationships, relationships which can accept a generalized medium of exchange, such as money, in the place of specific, socially imbedded goods and services.

For one example, bridewealth in Zinacantan in the recent past was payable only in a specific form, in big net bags of food in specified proportions and amounts. Acquiring some of these items required travel to neighbouring towns, dealings with alien producers, and a certain mature expertise in the social and financial aspects of such commerce, as well as the active support of one's father, upon whose wealth a young man had to rely. Today, bridewealth can also acceptably be paid in cash, which a young man can acquire through his own wage labor. Bridewealth in goods was, by its very nature, consumable; in fact it had to be consumed or it would spoil and go to waste. Once consumed it was hard to return - not impossible, but requiring a good deal of bother - and the social arrange- 
ment it symbolized was similarly hard to undo. Cash presents no such obstacles; it is consumed in a far less direct and specific way, and it can be borrowed and returned on a moment's decision.

Similarly, weaving labor appears once to have been a matter solely of social obligation, the labor given under certain circumstances and to certain people without direct or immediate reciprocation sister to sister, mother to daughter, aunt to niece. As such, it remained undefined by any specified value equivalencies for the purpose of sale or exchange. Today, as woven garments find a market in the tourist shops of the cities, women are struggling to determine a cash value for their labor input. Very young women and widows today weave for cash the garments needed in the households of their kinsmen to whom only two generations ago they would have given them freely.

We may surmise - and in part this description grows out of an anthropological myth about traditional Middle American societiesthat the ancestors of modern Zinacantecos once inhabited a society of thoroughgoing communality. Land, the principal resource, was held communally by the group; production was organized through corporate groups of kin (lineages). Moreover, ritual practices were aimed at securing the welfare of the entire group: each individual soul was to be in harmony with itself and with souls of other members of the domestic group; each house participated in common ritual with others who shared the same waterhole; the well-being of the whole community was the joint responsibility of ritual practitioners whose activities were subsidized by the entire population.

But Zinacanteco life, under the management of the Colony, the Republic, the Revolutionary state and its present descendant, derives from changed conditions which all conspire to render social relations somewhat more individualistic, somewhat more commutable today than yesterday.

Today, the capacity of the agriculturalist to maintain the family by the efforts of the family alone, unimpeded by social ties of kinship and cooperative ownership which characterize tribal horticulturalists, makes of the smallholder a potential social anarchist. In Zinacantan, the scarcity of land and the decreased productivity occasioned by land rent as a condition of production, have prised the individual producing household out of its social imbeddedness, leaving Zinacantecos to define and carry out their life choices individually within the parameters of the market economy and their position in it as illiterate, 
unskilled producers with an inadequate command of the national language.

Language and dress still set Zinacantecos apart from other Chiapas peasants, and there are still religious ceremonies that engage all members of the municipality and distinguish them from their neighbours, both Indian and non-Indian. But ethnic identity, for a Zinacanteco, is not enough to sustain commonality of interest, not enough to inspire cooperation or to ensure loyalty. It is more like a fence by which an individual Zinacanteco can shield himself from the outside, thus limiting the social universe with which he must deal.

3. The philosopher S. I. Benn has suggested that the distinction between the public and the private can be understood in terms of dimensions of access, interest, and agency. Here some preliminary observations are in order.

\section{1) Access}

In Zinacantan, as elsewhere, there are both facts of access (my house overlooks your yard; your fence is high; I can see the cards you're holding; the walls are paper thin) and norms of access (I avert my eyes from your cards; I ignore the sounds from next door $\rightarrow$. In 'face-to-face' societies, when people live close together, it may be the case that nothing of substance can be 'private' - that is, inaccessible. Privacy under such circumstances may be only an elaborate social sham. (One woman with whom we frequently gossiped in Nabenchauk lived on a high hill from which vantage point she commanded a view of the entire village. Yet she frequently asked us, feigning ignorance, about doings in our part of town about which she was undoubtedly well-informed. She pretended to know less than she did partly to observe conventions of propriety, partly to test our own knowledge, and partly to observe and draw inferences from our own fumbling efforts to disguise what knowledge we had.) The opposite case is also possible: a social system may permit invasions of territory seemingly inaccessible in principle. Psychoanalysts, Zinacanteco curers, even jealous lovers, sometimes pursue peoples' most intimate, most private, least observable states of mind. Zinacantecos go to almost pathological lengths to delimit the boundaries of access to goods, or to information. The patterns of access clearly index social seams. (A canonical example, in small social systems, is the distribution of access to names: who knows, and who 
has license to use, and with whom, full names, middle names, family names, patronyms, pet names, nicknames, secret names, and son on.)

\section{2) Interest}

In Zinacantan the relevant contrast is not between private interests and public interests, but between the competing interests of distinct groups of assignable persons. This is the point of Foster's notion of 'limited good' - the idea that there is only so much good stuff to go around, and giving you more means less for me; this is a kind of cosmology of human interests. But such cosmology does not spring, full-grown and unassisted, from native heads. What people understand of their own interests depends crucially on what there is for people to be interested in (as they perceive it), and on the conditions that govern access. In a contrasting case, the (often rhetorical) ideal, in many Australian Aboriginal communities, of shared resources and common interests derives from a perception that things are replaceable, reproduceable, and that everyone is in the same boat. (In an Australian Aboriginal community where we have worked, when someone catches a fish, the normal remark is: "That means there are some there for me to catch, too.")

\section{3) Agency}

In Zinacantan, control over resources and rights to decide about their disposition are vested in households. In our society these are largely matters of law. But in Zinacantan there are few sorts of legal authority which can crack the social atoms of the household. The case of Zinacanteco land tenure is instructive. Only in recent times have individual Zinacantecos had the opportunity freely to purchase plots of land from one another or from outsiders. It is still the case that a man may not part with his own land, land he has inherited from his parents, until he has established his own household. Even then, he is constrained to offer land that he may want to sell, first to other members of his former household, rather than to any member of the general public.

When we come to a village like Nabenchauk, we do not confront a place, a society, a way of life which we already command. We cannot rely, as we look at what is happening around us, on our ordinary presumptions, as competent members of the society. Our 
need is not only to untangle the conceptual underpinnings of our language in order to describe phenomena. We must discover as well what the phenomena are. Our problem is not a matter of classification or assignment at all ("Is this act public or private?"), but something rather more primitive: at this first stage of understanding, we must discover what counts as an act; we must locate behavior, belief, institutions; we must learn how to attach meaning to action, or ,to work out functions and purposes. (For the ethnographer in the field, there is often a further, pressing problem: how to behave oneself. And though we may not be completely at a loss, living as we do among other human beings, our blunders will be constant and of ten disastrous.)

Within this low level anthropological task, we may make three different sorts of appeal to a distinction between what is public and what is private. We may encounter native notions (as evidenced, for example, through forms of speech) about how social life is conceived by native actors themselves - notions that, for one reason or another, we may gloss by words like 'private' or 'public'. For example, when an event is described in Nabenchauk as taking place ta jamaltik, we may feel justified, given a certain context, in glossing the phrase which means literally 'in the open', as 'in public'. Second, it may be that a distinction between public and private domains - places, property, behavior, information - can enhance our ethnographic analysis, whether or not natives can be seen to employ such notions in their own social discourse. So, for example, we may say, felicitously, that certain behavior - say, a Zinacanteco girl's running away from a visitor - evinces a 'desire for privacy', even when the most the girl herself can say is tol chk'elvan, literally 'people look too much'. Finally, we make more contentious, rhetorical, motivated use of notions of privacy and publicness (appealing to a 'public good', or sneering at 'private interests'), as we evaluate native life; such appeals frequently figure in the discourse of agents of manipulative social and political change in a Zinacantan community of habitual victims, where 'development' is concerned.

Semantic analysis of concepts like 'public' and 'private' may well be possible for our ordinary usage, in the assignment to one realm or another of phenomena in the familiar domains to which the terms apply. Whether or not semantic analysis is possible in general - that is, in terms applicable to, discernible in, or appropiately and usefully derived from all (possible?) human societies - is another question. In any case, the wider our empirical net, the more societies we 
consider, the more likely we are to understand the parameters and needs of human social life which raise issues of privacy (and publicness). The important anthropological questions are: Why are there private versus public spheres? What social ends are served? Why and on what basis is behavior or are social relations organized on these dimensions?

4. In particular, in Zinacantan, what realms of experience are 'private' and what 'public' depends on the patterns of social relations, on 'facts of life' (deriving in part from the circumstances sketched above in our brief look at Zinacanteco history), and on the cultural interpretations placed on these facts. Logic or semantic analysis alone may help us sort, but cannot generate, the social choices and circumstances that underlie Zinacanteco privacy; only a detailed look at some fragments of ethnography will tell us how Zinacanteco experience is cut into public and private slices.

For Zinacantecos are, speaking in ordinary terms, extraordinarily private people. This description confounds a common image of small-scale, 'face-to-face' communities, where people are supposed to live in one another's pockets: to have access to everyone else, to have some reason to be interested in them (by virtue of, say, corporate, familiy-based ties to them), perhaps even to have some say in what everyone else does. According to this common picture, such matters are taken both to be given by physical (brute) facts - proximity, limited resources both material and social- and to have normative force: there is a supposed ideology of communality.

But in Zinacantan, privacy is, first, a matter of plain geography. The valley of Nabenchauk is rimmed by three intersecting ridges, which form a roughly equilateral triangle. The village houses hug the slopes of these ridges and cluster on the higher portion of the valley floor. At the three points of intersection of the ridges are the passes through which foot trails wind down into the valley from other Zinacanteco settlements. Through the northwest corner a rock paved truck road enters the valley, straight down to the plaza in front of the church.

Here in the center of the village is the town hall, a government grocery store, four cantinas, and the church, all spaced around the recently terraced and paved plaza area which is a product of the public works projects run by the state government development agency, PRODESCH.

The plaza is the scene of public dispute settlement, whose focal point is the verandah of the town hall. Except during the Saturday 
morning market, when it is abustle with men, women and children of all ages, the plaza is a rather large and empty place, too open, too formal for people to sit or even to pass through comfortably. Little boys confine themselves to playing in the dirt beyond the paved square, and rarely climb on the slide and teeter-totter; women skirt three edges of the plaza in preference to crossing it. Only older boys congregate in the plaza, and they line up along the steps at its edge to overhear the court cases in front of the town hall.

The plaza is, of course, the most 'public' part of town. Next to it, the broad roadway which runs through the middle of the valley, the trails which lead out of the valley, and the footpaths which run along fences and through cornfields connecting the houses to each other are public areas, of free access, and of public, constrained behavior. Last, there is the lake bed and its flood plain, owned but not tilled, and anyone who wishes may walk there, graze sheep or horses there, and use the wells and the washing stones beside them. For the rest, all the land whether valley floor, rocky slope or wooded mountain top, is privately owned.

Almost all the tilled land is fenced in Nabenchauck, no single piece of it larger than three-quarters of an acre. The fields are fenced against straying sheep, and turkeys, and against the hungry dogs which run down young corn plants, and will eat corn raw in the ear. The house sites also are fenced, against animals and against the trespass of other villagers. Where a footpath passes close by a house, the fencing is often built up by long pieces of split oak firewood stood on one end and stacked close together to obscure the view to a height of five or six feet.

Almost all of the houses in Nabenchauk are constructed of unplastered adobe brick and roofed with red clay tiles supported on timber beams. Most houses are rectangular, four to five metres by three to four metres, and contain a single room. The cooking fire is built on the packed earth floor, and the smoke escapes upward, unobstructed by any ceiling, through the roof tiles and under the open eaves. No window penetrates the thick brown walls of these houses; the only light which enters comes through the open doorway.

There is no place in the village where a person can be certain to be hidden from the gaze of other people. Years of living with other people in close quarters undivided by interior walls have provided Zinacantecos with many ways of preserving personal modesty, chief among which is the trick of remaining fully clothed at all times, even in sleep. Privacy within the household is also guaran- 
teed by a sense of responsibility for the modesty of others - when intruding unintentionally on someone, one simply averts the eyes. Within the household one is as careful of another's privacy as one is of one's own. Beyond the household, however, such constraint is quite lacking.

The space outside the house itself, within the fence or yard boundaries, is the workplace of the home. On an ordinary day, several activities are going on at once in the yard - the children are playing, someone is weaving, someone else repairing a chair. The yard is a space shared with chickens, turkeys and dogs, who wander continually through in their forages and who must be watched out for lest they soil the weaving or steal a bit of food. In most cases, it is also a space open to prying eyes, often, in this mountainous place, prying from a considerable distance. This lends a certain ambivalence to attitudes toward this area. One assumes that anything done there can be observed, that anything said there above a whisper will be overheard. Even in a well-sheltered patio a woman's weaving can be heard in the resounding thump of the beater, or seen as the shaking branches of the tree to which her loom is tied.

This is in part a good thing: if one has nothing particular to hide at the moment, one is exhibiting this fact to those who are interested, while keeping in good position to see and hear the doings of others on the paths or in their patios. Much of the conversation that goes on between people working in the yard is speculation on the immediate affairs and destinations of the people visible from this vantage point. Similarly, staying indoors or, even more unheard of, closing the house door, is a gross and open admission of being up to no good.

A Zinacanteco house is a private area; it is 'set apart'. E. Z. Vogt (1969: 89) writes of the Zinacanteco house compound that 'the patio is of social significance because often guests are entertained there rather than inside the house'. However, the choice between inside and outside the house is not just random (a matter, perhaps, of the weather) but significant. There is a scale of admission to the house compound, when visitors arrive, as follows: On the path / just outside the gate / in the patio / on the porch/inside the house in the "visitors' area" (far from the fire) / by the fire. Entry to each new stage, for a nonmember of the household (even an intimate kinsman) is by invitation only, and most people do not get beyond the first few stages, on most occasions.

A new house is dedicated by completing a ritual circuit around 
it, to protect it from the outside. One cannot sleep in a new house until its sides are secure, its orifices sealed. It is spoken of as a sick person (whose soul is not well-fastened to his body). Moreover, with illness, during a period of seclusion (and after childbirth) a patient can leave the house only if guarded, and no visitor may enter the house.

The isolation of the house is more than just conceptual: it is material as well. Zinacatenco houses do not have windows. (And when the government development agency built houses for Indians with large, unshuttered windows, their owners carefully papered the windows over or bricked them in. Windows are for ladinos, nonIndians, who can sit by the windows where everyone can watch them eat.) Fences surround the yard, and the common phrase to describe one's private place, where members of a household can relax in their own company, is ta yut mok 'inside the fence'. There one hopes to be relatively safe from prying eyes, though people watch for spies (there is a monolexemic Tzotzil verb which means 'to observe in secret, from a hiding place') and complain bitterly about new roads near to their yards that allow passers-by to 'look at you'.

All space in Zinacantan is carefully divided by categories of access. You can step up to my gate uninvited, but you can't come in. My brother can draw water from my well, but my cousin can't. Anyone from Nabenchauk can walk into the church, but others have to ask the sacristan. Anybody can graze his sheep near the lake, but only I can chop wood on my plot of forest land. What we have called 'public behavior' above means, in this context, what one does in public places - places of unrestricted access. In Zinacantan, in fact, public places constitute a socially restricted arena, where one monitors one's behavior all the more severely for being in the public eye.

5. The tension between what is private (often, even, secret) and what is public (or allowed to leak out) is most obvious in interpersonal interaction, especially in conversation. Ordinary talk between Zinacantecos is, in fact, almost the canonical case of social intercourse and the properties of conversation give instructive examples of the tenor of Zinacanteco social life.

Consider how ordinary polite talk in Tzotzil differs from English conversation. On Grice's (1975) well-known analysis, cooperative principles which operate in all well-formed conversation (at least, in the circles Grice frequented) enable a range of interpretations 
and inferences not available from, for example, the literal meanings of utterances or from discursive conversational organization alone. These principles constrain participants in conversation to make their remarks relevant, to speak the whole truth (as much as they know within a given context) and so on. Two Gricean examples illustrate these maxims of relevance and quantity:

\section{A: I am out of petrol.}

B: There is a garage around the corner.

(Allowed inference: you can get petrol there.)

A: Where does $\mathrm{C}$ live?

B: Somewhere in the south of France.

(Allowed inference: I don't know anything more exact than that.)

These maxims are disobeyed from time to time for particular purposes: to be deliberately perverse, to snub, to mislead, and so on.

Elinor Ochs Keenan (1976) has suggested that these principles do not obtain (or, at least, not as stated for English conversation) for Malagasy speaking peasants, in Madagascar. There, she argues, information is treated as scarce goods; what's more, Malagasy peasants espouse an ideology of the collective responsibility for action that causes people to avoid any action that draws attention to individual ability, or that commits people to individual responsibility. Malagasy conversation, according to Keenan, is non-committal, indirect, guarded, and often, for the Western ethnographer, deliberately stripped on both relevance and quantity.

In a similar way, ordinary polite conversation in Zinacantan is marked by formulaic inanity. On the path one asks another: 'Where are you going?', and receives the ordinary polite reply: 'I am going nowhere'. One asks another about the purpose of this errand: 'What have you to say?' The answer, belied by the occasion, is commonly: 'I have nothing to say'. In many Tzotzil conversations, one party seems to be trying his best to pump information from his interlocutor, while the interlocutor uses his every ploy he can to evade, and deflect the other's purpose. The formulas of polite conversation set a tone in which Gricean cooperative principles are turned off.

A striking example of the metaphor of ordinary conversation can be seen by comparing standard greetings (for example, when people meet on a path) with 'full conversations' in English and Tzotzil. In both cases, a conversation typically has an opening ('Hello', how are you?'), a body (during which some matter is discussed), and 
a closing (which in turn has an opening gambit and an end: 'Well, I've got to be going', 'OK, see you'. In English (or, at least, American), a reduced greeting exchange is lifted from an opening sequence:

'Hi, how're you doing?'

But the standard greeting in Tzotzil is taken clearly from a closing sequence:

Chibat che'e. Batan!

I'm going. Go then!

A Tzotzil greeting constitutes a metaphorical shutting down of interaction and communication. A greeting is, formally, a farewell and not a hello. (In either language, of course, a greeting is essentially empty, a hollow interaction at best.)

Looking at ordinary talk in Nabenchauk leads to the conclusion that all information is taken as inherently dargerous; that people's interests are thought to be inevitably opposed; that access to one another's business invites not shared confidences but breaches of confidence. Living in Nabenchauk involves, as we shall see, constant circumspect hiding. Tzotzil conversation is kinesically well contained. As novices in the village, and as potential inadvertent blurters of household secrets, we were constantly tutored in conversational conventions, often instructed in precisely how to talk about (or to avoid talking about) private affairs.

Here a brief semantic detour may be in order. There are, so far as we know, no Tzotzil words for 'public' or 'private' (despite elaborate syntactic mechanisms for marking possession obligatorily). But consider the sorts of verbs that appear frequently to describe what happens to information:

-vinaj
-lok'
-lik
--?il-e
-?a?y-at
-lam
-paj
-mak
-nak'

\author{
'appear, become perceivable' \\ 'emerge, become public' \\ 'arise, begin to circulate- \\ 'be seen, be obvious' \\ 'be hard, be perceived' \\ 'be eased, grow less severe' \\ 'cease' \\ 'be covered up' \\ 'be hidden'
}


-muk

-laj

—ch'ab

一?ep-bat

-muk'ib

—ch'amuj

-batz'ij

-kechi 'be buried, be kept secret or private;

'finish'

'disappear, cease to exist'

'increase'

'enlarge'

'spread'

'become more severe'

'remain, be left over, persist'

These verbs, applied to gossip stories, evidence a Tzotzil theory of information and reputation that clearly involves notions of privacy and publicness.

In Nabenchauk, what is private is a matter of gradually (and, one might say, grudgingly) widening concentric social circles to which villagers may belong. What is private, what is one's own, pertains to what is inside the circle; what is public, open, (and usually, potentially dangerous) is what remains on the outside. (In fact, for Zinacantan, 'private' seems logically the primitive term; 'public' is a residual category, defined by opposition to the well-bounded closed private domains, with no independent motivation - no notion of 'public good' or 'general public'.) But the smallest such circle may not be as small an object as a single, psychologically self-aware individual-socially, there may be no such creature. (Equally, we can imagine societies in which the smallest social unit is less than a single person: a manifestation of an aspect of one person's personality, perhaps, or a spirit - who knows what remains private in an asylum?) In Zinacantan, one starts life as an adjunct to one's parents or grandparents - one's name is usually even a possessed form: $y$-Antun li mol Petul-e 'Old Peter's Anthony'. Full social identity ordinarily comes only when a person establishes his or her own household. Zinacantan, like many other societies, provides a well-demarcated natural class: the household, the paradigmatic basic family.

6. Every person in Nabenchauk has one and only one -na 'house' which he can claim as his or her own. Statistically, and ideally, households in Nabenchauk are small, usually containing only a nuclear family, although the period of postmarital patrilocal residence, which may last between one and five years, creates periodic extended family households. Sharing a household can be defined as eating together. Zinacantecos do not indiscriminately lump together the fruits of their individual labors and share them out willy-nilly. 
If two men eat together every day tortillas made over a single fire, then they have worked together on a single patch of land to produce the corn that is in the tortillas (or pooled their cash resources in an explicitly agreed way to purchase it). Put another way, two Zinacanteco men who farm separate pieces of land keep their harvests separate and eat separately; people who eat together around the same fire, that is, share the ownership of the staple food resources by definition.

Take the case of, say, an old woman who sleeps alone in her own house. If she eats in the house of her married son or daughter, then she shares in the ownership of the corn supply in the same manner as a child in that household does. If, however, she cooks for herself at her own fire in her own house, even though she eats mostly corn supplied to her by her children, producing little income for herself, she does not share in the total corn supply of her children at all. Rather, explicit gifts, or loans, of corn (or cash) are made to her by her children and the ownership of that food, the right to dispose of it as she will, is transferred to her. No fraction of the harvest automatically accrues to her, nor can she simply consider her children's resources to be her own. Bag by bag, she must acquire her corn in gifts, formally and explicitly made by them, or formally requested by her.

Lest this be interpreted as a mere formal nicety, it ought to be pointed out that many old women with prosperous offspring go about in rags for lack of the wherewithal to buy new clothes.

In any event, the only time in Nabenchauk that ownership, in exact quantities, is left vague is when all parties share meals in common. The actual organization of the labor input to the production of staple resources and other necessities will be dealt with later. When sufficient land in available, young married sons prefer to build their houses on land contiguous to their father's land. This may result in a compound of two or possibly three related households, each with its own house and courtyard within the same fence.

With regard to matters of crowding and of personal space - personal body privacy, work space, the noise of children - there is little difference between a single dwelling, or several around a central courtyard. What does change significantly when a second household is set up is the question of ownership and the privacy of one's financial affairs attendant upon private ownership. A second household requires a separate supply of corn, separate cooking equipment, and sooner or later separate work tools for farming, weaving and regular maintenance work. Ownership of any item is never ambig- 
uous between Zinacanteco households, although the freedom to borrow back and forth can be extensive when relations are good.

The existence of more than one household as defined here implies the existence of two or more economic units which are at least partially distinct. Where farm land is involved, it will have been divided, as will the household goods. Articles will be bought and sold separately, with separate purses carefully maintained, right down to the cost of the grinding of a bucket of corn which may amount to only 10 centavos. This means that in time, and no doubt in a very short time, both real differences as well as perceived potential differences in the interests of the two households can arise.

The coming and going of visitors will be noted between households, but the actual transactions can go on behind the walls of a house, and at night behind closed doors. Visitors to one household in a compound not infrequently time their visits to occur after everyone has closed his doors, and will enter the yard as silently as they can, whispering at the door of the house they wish to visit. At the very least, such occurrences of events involving one household - a sudden visitor, a shout in the night, whatever- put the other household in the position of knowing that something has happened without knowing what. They then must wait to be told about it spontaneously or be bold enough to ask about it themselves, which amounts more or less to a constant test of the extent of mutuality and trust between them. This is a situation of structural ambiguity - separate units with close historical ties, physically close enough to know of one another's business without knowing, as a matter of course, about it. Both inquiring and not inquiring, telling and not telling, are active responses in a situation of this sort and tension and curiosity are the inevitable result. The existence of more than one household in a compound by the very nature of the Zinacanteco household raises ambiguites about space and property that may be at the root of the empirical finding that Nabenchauk residents consistently choose to live either in larger single households or smaller single households and appear to avoid extended family compound living arrangements.

7. The domain of the private in Zinacantan, then, is the individual household. What goes on ta yut jmok "inside my fence", inside my own house compound, takes place in a protected, private, social universe. Publicness means outside the fence, and its dangers are not unlike the dangers, at another level, of the surrounding te'tik 'forest', or of the non-Zinacanteco world of the local Mexican 
towns where different social rules are in force. However, much ordinary social life must take place outside the fence: sociability and publicness are linked conceptually, and danger is involved. Social life requires display of self, invites others to - k'elvan 'look at you', and exposes one to the possibilities of k'exlal 'shame' or -ak' 'elav 'making a spectacle of oneself'. The defining conditions of Zinacanteco life, the circumstances of productive life, provide for a certain necessary interaction between social units, and all involve potential breaches of confidentiality. They do not, however, promote a higher level of publicness. We shall consider ordinary sociability, features of Zinacanteco marriage, and cooperative labor as telling examples.

The realities of domestic tasks in Nabenchauk require that a good deal of the household routine has to be carried out beyond the confines of the household fence. Corn, which has for generations been ground by hand on a stone metate, by the hearth, is today taken to electric corn mills dotted about the village. These are places fraught with social dangers, and in them constrained behavior is at its extreme. Women carry their buckets of corn in the crooks of their arm, covered by the lower edges of their shawls; buckets which are carried hanging from the hand by the handle most of the way from home will be shifted to this covered position as the mill is approached.

As soon as women or children come within a few meters of the mill they lower their voices to a whisper and most conversation ceases. Shawls are raised to cover the mouth, and each person takes her place in line silently, raising her eyes only to scan newcomers in a wary fashion. Once inside the mill people rarely greet each other openly, although some adolescent girls, taking what may be their only opportunity in a day to see one another, often allow friends into the line ahead of them. Most mills have a bench or table on which waiting customers may rest their buckets. Women carefully keep their buckets of corn in order in the line, their rims just touching. If a newcomer is allowed into the middle of the line, each woman in adjusting her own bucket is very cautious not even to touch the bucket of another. 'To do so is regarded as taking a very great liberty.

Another ceaseless daily labor of women is carrying water. The most common time for women to go to the standpipe is just after breakfast and in the late afternoon. Girls and young women, unablefreely to visit one another's houses, time their regular trips for water 
to coincide with the trips of their friends, and in this way can exchange gossip in low whispers as they walk together on the path. But in Nabenchauk these social moments do not in the least resemble the very garrulous and convivial tones we have witnessed at wells in the water-scarce western villages of Zinacantan where houses are clearly clustered in patrilineal groups, each group with its special hour for water collection at the community well. In Nabenchauk one may meet anyone at the standpipe, and the eyes of any of fifty houses may be watching. It is a moment for very guarded behavior indeed and, as at the mill, women do not gather at the watertap itself, but may cluster in small groups of two or three some five or ten meters away where they cannot be approached except by friends joining the conversation.

Waterholes have two related social aspects: they are both sociable and public. Washing at the waterhole can provide a woman with a good occasion for a prolonged chat with women of other households, an opportunity unequalled by any other task. Since no Zinacanteco drops in on another without good reason, people, and particularly women, can find themselves talking to members of only their own households for days at a time. Even though life is generally unhurried, women do not stop long by the path or at the shop to talk with others lest someone observing take note and make something of it. But washing clothes is a very long business, and who can think ill of anyone for spending an hour or two at the chore chatting the while? For all their anxieties, Zinacantecos love a good joke and women washing clothes are rarely sober faced and are even, on occasion, boisterous.

On the other hand, these waterholes are undoubtedly public places with all the danger of one's conversation being overheard, or of being joined by someone one would rather not encounter. Groups of women at a waterhole may laugh and joke continuously, even obscenely, but never freely. They remain ever ready to parry a remark aimed to catch them off guard; questions like 'Where were you going up past the cemetery yesterday?', or 'What did you buy in town when you went the other day?', must never be answered directly, but cleverly sidestepped with an implied denial or a vague reply, or outright lie.

The-women of Nabenchauk on any Saturday morning will take produce to sell at the village market. Indians of other ethnic groups as well as lowland Ladino peasants and potters come to this market to exchange their vegetables for fleece, corn and flowers. These 
foreigners spread their wares in wide circles around them, and settle themselves on chairs or tarpaulins in a very comfortable manner, often buying soft drinks from the nearby cantinas, lounging back, legs akimbo, to snack on fruit or peanuts, shouting to one another, laughing and verbally accosting the Zinacanteco shoppers as they pass by.

To this rather common market behavior the demeanor of the women sellers from Nabenchauk could not present a greater contrast. Each woman or girl sits with her belongings closely gathered around her, occupying in this large plaza the smallest space she possibly can. Her legs are tucked under her in the usual manner of sitting, her shawl drawn up over her mouth, her eyes cast downward or at least carefully avoiding meeting the gaze of others. Everything about her seems to say, 'I am not really here'. This is quite normal public behavior for most Zinacanteco women, in particular for adolescent girls and young women, and this description accurately reflects their demeanor as visitors, as spectators at a fiesta and as they simply wait on a street corner of San Cristobal for a truck or bus. But in this case on Saturday morning they are there to sell something; whatever it is it will most likely be well out of sight, wrapped in one of the white cotton flour sacks ubiquitous in the highlands as luggage containers, or in an layer or two of red and white woven bags. Perhaps in front of them will be displayed one or two samples of the goods they are offering; perhaps the passerby will have to inquire what it is they have for sale. Many women will avoid looking at their interlocutor at all as inquiries are made or goods and money exchanged.

At one level this reflects propriety of manner, and also a nervousness about encounters with strangers. It also, however, reflects the extreme discomfort they feel at making known their intentions and their goods in this place which is not merely public, and filled with strangers, but, even worse, filled with villagers and relatives who will thus learn the nature and extent of their business.

In Nabenchauk there are only two legitimate occasions for social intercourse with members of another household: business and ritual. Business interactions in this peasant world are far from impersonal, but they are nonetheless restricted to the business at hand, relatively brief, and unlikely to involve anyone but the principals to the deal. They may, however, occur between virtually any two households, related by kinship or not. Ritual occasions, on the other hand, bring together members of different households, ofen for days at a time, 
eating and sleeping and working together. Such gatherings almost always involve households related through kinship.

Apart from these kinds of events, social interaction between members of different households rarely will amount to more than remarks made in passing, or otherwise brief, guarded and purposeful interchanges. Informal, prolonged, or intimate contact is relatively rare, but when it occurs it is sure to be between kinsmen or between the pseudo-kin created through the institution of compadrazgo. The essential point about village social life, then, is that virtually all social intercourse is guarded and purposeful whether between kin or non-kin, but insofar as deeper intimacy is ever achieved, it is possible only between kin. Conversely, kinship does not carry with it the obligation of intimacy, only the potential for it.

Propriety dictates that the impetus in a marriage proposal come from the young man, who watches eligible young women as they go about the paths of town, and makes his choice as he can from what he sees and hears of them.

Most opportunities for young people to observe one another are limited to public moments - to passing on the path, standing nearby while observing a fiesta or while attending a market or riding a truck. Moments such as these are precisely those in which Zinacanteco behavior, particularly female behavior, is most restrained. Voices are lowered to a whisper, the gaze is averted, mouths may be covered by a shawl, or by a man's neck-scarf. At such times even to hear clearly the voice of a possible mate, let alone overhear her conversation, is practically impossible.

The children, however, of one's mother's sister or brother may well be people one has seen on a regular basis since childhood, at weddings and religious ceremonies, while hanging around the washing well or on a wood gathering trip. Over the years young people so related may have spent many hours within sight and earshot of each other, while each is playing or, as older children, helping with the work. This degree of knowledge is something one is highly unlikely to hold about young people unconnected to one through kin ties. Similarly young people living in the same part of the village will have many more opportunities to observe one another, albeit at some distance and perhaps clandestinely, than do people separated by such distances that they do not cross paths often. This simple issue of opportunity and intimacy of knowledge more than any other determines the frequency with which matches are sought between neighbors and collateral kinsmen. 
During a courtship, and following the marriage, the natal households of the marriage partners come into, for Zinacantan, intense contact, in particular during the years which the new bride will spend in the home of her husband's parents. And while the choice of a bride is considered to be the prerogative of the young man, and ultimately will result in a household headed by the two young people quite independently of their families, the marriage will have deep day to day consequences for two or three years for the members of the young man's household. An example will best illustrate the interests involved.

In the winter and spring of 1976 a difficult marriage was concluded between Q, the son of our neighbor, and Y, the daughter of a widow living nearby.

During the first few months the bride maintained a reserved and polite demeanor, rarely speaking unless spoken to, working alongside Q's mother and two adult sisters, occasionally sitting alone on the stoop staring wistfully into space. She never spoke directly to her new husband within anyone's earshot, nor he to her. Her life in the household was complicated by the presence of Q's two sisters, both spinsters in their late twenties who already formed a close pair, a social and emotional bond which was threatened by the arrival of a third young woman, and a relationship which had the power to exclude her.

The two sisters admired the weaving skill of the bride at the same time that they felt competitive with her, a competition which had gone on for some years. Neither sister had ever spoken to $\mathrm{Y}$ during adolescence, although their homes were separated by less than 100 meters. Both sisters reported Y to be an amiable and competent person against whom they had only one bitter complaintthat her presence in the household required everyone to be very closemouthed at all times because she would carry tales of the family affairs back to her mother's home. Y visited her mother every Sunday morning when $Q$ was away, although she was suspected of doing so whenever she left the house yard for any reason, and during her absences the women of the household speculated continuously on what she was telling her mother about them. Everyone in the household was constrained in her presence to keep talk of political matters and quarrells with other households to a minimum.

Members of the household grew anxious and exhausted from having to live with a person in their midst who, regardless of her personality, was inevitably a conduit to another household of dangerous information about them. Quite apart from the hostilities between the two natal households over the marriage itself, everyone in the husband's household felt that to put another household in possession of private information about them would be intolerable. The husband's sisters remarked to me that it was simply a matter 
of waiting until the young couple moved into their own new house, which they would probably do as soon as Q could afford to build one.

A tremendous advantage accrues, then, to marriages made betwen members of households which are linked already, whether through an earlier marriage in the same generation or in the previous generation, provided good relations exist between them at the time. A bride already known to her husband through childhood associations will be known to his sisters and mother, raising the potential for satisfactory relationships among them. Households related already will find the period of the bride's residence in the husband's family home less threatening, as more is already known between them of each other's affairs. Preexisting good relations between the households will provide already established means for working out quarrels between the bride and her in-laws, as well as bringing help from both sides of the new family to resolve conflicts between the new partners themselves. Marriages between cousins have the important consequences of providing a network of relationships linking the bride to her mother-in-law, with whom she has the most intense contact in her new situation. It is important to mention, however, that these considerations, however helpful they are to working through the tensions of establishing a new nuclear family through the members of two independent households, do not guarantee that good relations will continue among them over the years.

Once children are born to a new couple, the issue of the ultimate disposition of the fruits of productive labor, especially male productive labor must arise. The new child represents the beginning of a new generation, whose patrimony must ultimately be separable from that of other potential lines of inheritance. The joint labor of a man and his unmarried brothers can no longer be equally divided, nor do the brothers stand to inherit any longer from the new young father, whose property now ultimately belongs to his offspring.

Land and goods are always passed from parent to child. Siblings never inherit directly from one another, but they do stand to benefit or to be disadvantaged by each other's actions, as wealth amassed by one can be reclaimed by the father and redistributed among his children in times of ill will. Fathers retain the bulk of their property in their own hands until death, distributing it according to their own preferences at that time.

Siblings, then, remain in competition with one another for parental favor throughout the life of the parent, and tensions between them 
over responsibility for the ageing parent grow over the years. The issue of the ultimate division of property can pit the interests of one household against those of its closest kinsmen; the more closely related the households, the greater the interest in each other's affairs, for the more each one stands to lose or gain by that interest. In this way, households related by kinship have far more potential for acrimony and feud than do those not so related, and the social resource which family ties represent in Nabenchauk is easily turned to liability.

8. The overall peasant character of Nabenchauk conceals an element of wage labor and trading activity which not only provides the sole income of many households but importantly contributes to the subsistence of all the rest. Thus, while the village of Nabenchauk contains rural cultivators who are classical peasants -rural landholders who produce both for subsistence and for the market, and upon whom others of greater power exercise an exaction of productivity, in this case in the form of rent- this very fact itself produces a degree of stratification within the village.

The fact of rent payments keeps the average farmer on lowland fields producing (for his family consumption) at or below the subsistence level, which means, functionally, with little margin for error. In a world in which non-farming possibilities are scarce this means that within the village few are producing a surplus and many may be producing less than they consume. Over time, the vagaries of crop failure, the expenses of illness and other personal disasters, will produce a stratum of peasants who are falling behind. Those are the circumstances in which highland land is sold, in which traders or successful farmers will buy up the corn crops of farmers in debt and sell them back over the course of the year as prices rise. These are also the situations which villagers seek to avoid by more or less intense petty marketing of eggs, flowers and weaving products, by wage labor and by liquor distilling.

When peasants are producing a surplus in Nabenchauk they have several options. They may invest socially in participation in the hierarchy of religious offices (or cargoes); they may invest in brokerage between Indian producers and the market, either by reselling Indian produce to Ladinos or Ladino goods to Indians; they may invest in non-agricultural production such as liquor distilling or they may invest in land as it becomes available, i.e., at the expense of underproducing peasants. This process of internal differentiation is critically influenced by the existence of land rent. 
'Thus a village like Nabenchauk is not homogeneous in terms of access to productive resources like land, and to small capital items like stills and mills, and to the necessary supportive resources which go with land such as woods, water, and pasture. The more productive activities a household can undertake, the wider its economic margin for disaster, and in many cases this is a feature of how much land a household has to exploit. On other dimensions, however, households, as families, differ as well: the quantity of male labor, of female labor, of child labor, balanced against the number of mouths to be fed and backs to be clothed.

The division of labor by sex, which remains the most significant division of labor internal to this society, while stregthening the malefemale cooperative tie, also renders the conjugal or nuclear family -in technological terms, at any rate- self-sufficient in production (self-sufficient in relation to other Zinacanteco househols, although not in relation to the wider society and its markets).

In Nabenchauk most work tasks are structured in ways which allow them to be carried out from beginning to end by a person woking alone. Men can and do farm alone, for no aspect of the work so rewards cooperation that men are forced to maintain social groups for its sake alone or fail. The weaving, gardening, cooking and washing which women perform are also arranged for the solitary worker, although the pressures on a woman's time created by the birth of children will innundate a single woman's capacities. The solution to this in Nabenchauk is not the maintenance of extended family residential arrangements nor the creation of social obligations between kinsmen but the establishment of paid services for weaving and cooking between households. This is an example of a primary characteristic of the social, relations of work in the village: all labor is paid labor.

The only point in the corn cycle in which the labor of more than one man is absolutely essential is weeding time, when a single man working more land than he can weed quickly risks losing his corn to encroaching weeds. At other points in the corn cycle, a man can choose to exploit his own labor to the maximum and simply begin sooner and end later any one task than he would with help. The essential point is that additional labor in the swidden cultivation of corn on the rocky sloping and which Zinacanteco renters farm, land which is not suitable for plow technology, is a matter of aggregating like units of labor and not of complex cooperation. Each man works alone, even if side by side and in timing with 
fellow workers. A man and his young sons or a man and his paid workers will rise together, eat and go to the fields, beginning work at the same time, the man generally setting the pace for his workers by his own example. Side by side they will work, each man to his own row, moving up the hillside together.

They work together for company and motivation, stopping to chat and laugh together, to have a drink and a moment's rest. They enjoy one another's presence over the fire in the evenings, and take comfort from the nearness of other human beings in the darkness of the night. They work together to accomplish the cleaning or weeding or the harvesting of a whole field as quickly as possible. But the adding together of all these equal units of men's labor does not increase productivity in any way. It is the difference between one man working six days or six men working one day. Except for weeding time it makes little difference to the yield of the field.

Aggregating labor, whether through the presence of several workers in the household or through hiring workers, does allow a greater extent of land to be worked under the aegis of a single man, thereby increasing his overall net yield for a season by cultivating more land. Aggregating labor does not, however, increase the yield per unit of land cultivated. Thus the actual tasks of the corn cycle do not materially require cooperation, nor do they reward it with higher productivity.

Because landlords prefer to rent land in large blocks, Zinacantecos often form renting groups to acquire land, and then parcel it out among themselves. Within these farming groups the division of the land, and the working of it, is carried out on the basis of household membership: men do not pool their labor unless they are members of the same household, although they may work for one another for wages when one member of a renting group is falling behind schedule. Members of renting groups often travel together to their fields, and sleep and cook together around a single fire.

An association of men for renting in the lowlands is likely to be formed on the basis of kinship because kinship is the primary social link which exists between households in Zinacantan, but this link does not have the force of a necessary association; neither ritual nor economic forces require the maintenance of social bonds between households. The concentration of productive resources and of consumption in the household unit is so strong that it precludes the formation of social units larger than the household. 
It is important in the analysis of a community like this one not to take the services which Zinacantecos render one another for what they are not; formal reciprocities, wages, and purchases are not informal sharing of resources or expressions of elastic and enduring social obligations. Zinacantecos actively avoid being obligated to anyone, and they actively reject responsibilities for others; they are equally ambivalent about being debtors and being creditors. Life in Zinacantan is primarily about the acquisition of property -land, cash or corn - and the business of life is the work necessary to this acquisition. The virtue in the work is the virtue inherent in the property - the independence, and freedom from being controlled which it is hoped it will bring.

Many households do not contain the necessary personnel to maintain the full cycle of male and female production; these incomplete units do not undergo incorporation into larger family groups but maintaing themselves through the sale of their labor to other households. No social obligations exist between adults in Nabenchauk which compel a person to care for another in time of need: between brother and brother, sister and sister, father and son, money is lent, not shared, work is paid for, not pooled. It is perfectly possible to starve to death, alone in one's house, in Nabenchauk.

The replication of new nuclear family households in each succeeding generation is generated through the replication in each individual of the tasks of self-maintenance, as children acquire notions of private property within the household, learn to carry out their work entirely on their own, and come to expect to own full rights in the proceeds of their own work. To the producer belong all rights in the product, and Zinacantecos appear to like to keep accounts straight right from the start. The distinction between mine and thine is fundamental in this village, and is allowed to become blurred only by those foolhardy enough to risk being cheated or taken to court.

At the same time, the technology of production neither requires nor encourages cooperative organization within the village. Access to the means of production - whether land or wage labor- is to be had only through individual recourse to sources which lie outside the social boundaries of the village. No ties between producing units in the village are materially required, or materially rewarded. Instead, scarce resources pit households against one another through the market economy which has eroded the obligations and interdependencies of kinship by directing ties outward to the wider economy, 
and which has transformed socially embedded goods and services into wage labor. This then, is the productive organization which underlies the social atomism of Nabenchauk, or which, at any rate, does not conflict with it or require of individuals the maintenance of social bonds with others.

9. In Zinacantan there seems to be no sense of corporateness, no feeling for an 'all-embracing public good'. True, there is an obvious ethnic and linguistic unity about the place, and there is a religious hierarchy, recruited from all parts of the municipality, which assumes responsibility, year by year, for the rituals which maintain the patron saints of Zinacantan. However, the political and ceremonial cohesiveness of Zinacantan barely impinges on everyday social life in a village like Nabenchauk. Zinacanteco ethnic identity simply defines, for most purposes, the outer limits of the social universe. Zinacantecos, in the nearby Mexican town of San Cristóbal, more or less ignore non-Zinacantecos as mere human ciphers whose lives and concerns are of no importance. (This nearsightedness is, for Zinacantecos, a terrible sort of self-deception, of course, for many of the most crucial determinants of Zinacanteco life lie not only outside Zinacantan, but outside its influence or control.) Even within Zinacantan, however, that is good for me (and my household) is construed in opposition to, rather than as part of, what is good for everyone else. In the face of calls for cooperative efforts, spawned by local development agencies and usually phrased in Spanish rhetoric (la mayoría, el beneficio de la comunidad, etc.) members of Nabenchauk households express suspicions about the motives of the people concerned: what do they get out of it? what does it cost us? Social organization sets the parameters on the possible levels of the public or the private.

In a village like Nabenchauk, people's intense concern with privacy produces a constant feeling of constraint. The prying eyes of one's neighbors are felt to compel circumspection and conformity. Just as others are thought to be looking in from beyond the fence to observe one's private affairs, so too must one peer back across the fence in turn, to preserve one's own self-interest against their secretive behavior. There is a final paradox. As the watcher becomes the watched, as the imagined perceptions and thoughts of others become one's own judgments, the effort to preserve privacy results in the ultimate loss of freedom: the loss of an individual private life. 


\section{REFERENCES}

Grice, H. P.

1975 "Logic and Conversation". In P. Cole and J. L. Morgan (eds.), Syntax and Semantics 3: Speech Acts. New York, Academic Press, pp. 41-58.

Keenan, Elinor Ochs

1976 "On the Universality of Conversational Implicatures". Language in Society, 5: 67-80.

Vogr, Evon Z.

1969 Zinacantan: A Maya Community in the Highlands of Chiapas.

Wolf, ERIG

Cambridge, Mass., Belknap Press of Harvard University Press.

1966 Peasant. Englewood Cliffs, N. J., Prentice Hall. 